\title{
'The Best and the Brightest': Widening Participation and Social Justice in Contemporary English Social Work Education
}

Joe Hanley ${ }^{\mathrm{a}^{*}}$, Brunel University London, @joeehanley

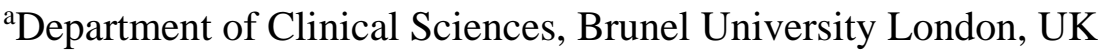

*joe.hanley@brunel.ac.uk@joeehanley

\section{Disclosure of Interest}

The author reports no conflict of interest.

\section{'The Best and the Brightest': Widening Participation and Social Justice in Contemporary English Social Work Education}

Social work education in England has a long track record of success in widening participation to disadvantaged student populations. However, more recently these successes have instead been cast as a burden that is negatively impacting on the calibre of students entering the profession. Alongside this reconceptualization, new fast-track models of education have been introduced, providing a quicker and more financially supported route of entry to the profession. This article critically examines the changing nature of widening participation in social work education and how fast-track social work programmes are perpetuating the inequalities that are inherent at all levels of the English educational system. This discussion is shown to have implications for widening participation policy agenda beyond social work. The concerns that are raised should be of interest to any other jurisdictions considering the possibility of a fasttrack approach to social work education. A social justice approach based on mixed-ability student education is proposed as an alternative and preferable model of social work education.

Keywords: Social work; fast-track education; widening participation; social justice. 


\section{Introduction}

Social work education in England has traditionally had a strong track record in widening participation (WP) to disadvantaged student populations, and should therefore have been considered as a model of good practice to emulate for other countries and disciplines (Jones, 2006; Fletcher, Bernard, Fairtclough \& Ahmet, 2015). However, most recently those successes have instead been characterised as an obstacle to overcome, seen as preventing the recruitment of high calibre students (Narey, 2014; Croisdale-Appleby, 2014). This reconceptualization of previously recognised successes opened the door for the introduction and rapid expansion of new fast-track models of social work education, aimed at candidates with strong academic credentials. The individual's taking advantage of these routes are more likely to be white, middle class, male and not have caring responsibilities than students on other social work qualifying routes (Think Ahead, 2017; Smith, Stephanova, Venn, Carpenter \& Patsios, 2018; Maxwell, Scourfield, de Villiers, Pithouse \& Le Zhang, 2018). The path that social work education has taken from WP champion to a segregated model based on the promotion of selective programmes is highly concerning, and raises serious questions, not just about the values that underpin the social work education system in England, but also the national commitment to WP in higher education. In light of these developments, this article will present a critical analysis of recent changes in social work education in England. A social justice model of social work education will be explored as a more desirable alternative, and one that is more aligned with the foundational values of both the social work profession and the WP agenda.

\section{Widening Participation and Social Work}

WP is a policy agenda that is based on widening access and success in higher education to those population groups who have historically been less likely to engage or succeed, including students from low income households, care-leavers, students with disabilities, mature students and students from certain ethnic groups (Connell-Smith \& Hubble, 2018). University graduates in England stand to earn on average $£ 100,000$ more across their lifetime than 
comparable individuals who do not obtain a degree (Department for Education, 2017). Therefore, the original impetus for WP policy was to counter poverty and social exclusion through broadening access to the benefits of higher education (Lall \& Morley, 2004). WP has had a particularly prominent place on the higher education policy agenda in England since the publication of the Dearing Report (National Committee of Inquiry into Higher Education, 1997) and remains a prominent policy theme in this area (Department for Education, 2017).

Fletcher et al. (2015) discusses that social work as a discipline is ideally situated to be a catalyst for change in relation to improving the experiences of disadvantaged groups in higher education, pointing to the profession's expertise on social inclusion, managing complex group dynamics and facilitating change. Unsurprisingly then, successes in relation to WP have been consistently recognised since the introduction of the social work degree as the minimum qualification for practice (Langlands, 2005; General Social Care Council [GSCC], 2007, 2009, 2010, 2012; Social Work Task Force [SWTF], 2009). Even while making these gains, the likelihood of gaining access to social work programmes has also increasingly been correlated to having higher prior academic qualifications (Holmstrom, 2014). Social work university programmes have maintained strong employment figures throughout this, with graduates being substantially more likely to be in employment within six months than the higher education populous as a whole (GSCC, 2010; Skills for Care, 2018). Social work university education in England has managed to consistently widen participation while also driving up standards, an achievement that has been recognised as highly elusive within higher education generally (Dillon, 2007; Brooks, 2017; Mallman, 2017).

Despite these achievements, there has always been more work to do. For example, black student attainment has continued to lag behind that of other students on social work courses (GSCC, 2012; Fairtclough, Bernard, Fletcher \& Ahmet, 2014; Liu, 2017). Building on the early successes, social work education should therefore have focused attention on continuing to widen access, promoting equality of outcomes and overcoming these remaining issues. Instead these early accomplishments have been gradually re-categorised in a negative light, 
highlighting a perceived tension between WP and the calibre of entrants onto these programmes (SWTF, 2009; GSCC, 2012; Croisdale-Appleby, 2014). In the highly influential Narey (2014) report into social work education in England, the perceived negative impact of WP on social work education was particularly prominent, and social work education was said to 'carry too much of the burden' in relation to the recruitment of 'students from low participation neighbourhoods, from certain socio-economic groups, with low qualifications and with a disability' (p. 16). While that report is now widely discredited due to its poor methodological rigour, overt author bias and substantial government interference (Murphy, 2016; Garrett, 2016; Cleary, 2018; Jones, 2019), it continues to be cited in policy to justify change and reform in social work education (Department for Education, 2016). Unfortunately, this change in focus has meant that the achievements in social work education in WP have not been considered as a beacon of good practice to emulate, but instead have been depreciated and marginalised (Fletcher et al., 2015).

\section{Fast-track Education and Rising Inequalities}

Alongside these developments, social work fast-track programmes have gradually taken centre stage in English social work education. The first of these, Step Up to Social Work [Step Up], was introduced in September 2010 as an 18 month employer led master's programme specialising in working with children and families (Children's Workforce Development Council [CWDC], 2010; Smith et al., 2018). Explicitly building on what were seen as the successes of Step Up, two additional postgraduate fast-track programmes were introduced in the years that followed: Frontline and Think Ahead, focusing on children's social work and mental health respectively (MacAlister, Crehan and Olsen, 2012; Clifton \& Thorley, 2014). A consistently stated goal of these fast-track programmes has been to recruit applicants who demonstrate academic excellence (MacAlister et al., 2012; Smith et al., 2013; Clifton \& Thorley, 2014). All three programmes have stipulated that they require applicants to have an upper second class honours degree or higher (CWDC, 2010; Think Ahead, 2017; Frontline, 2018a). Beyond this, an emphasis has been placed on the types of institutions that their applicants have come from 
as a mark of quality (MacAlister et al., 2012; Clifton and Thorley, 2014). For example, Think Ahead (2017) advertise that $14 \%$ of their participants are from Oxford or Cambridge, compared to just $0.5 \%$ of all new social work master entrants.

A significant oversight from a social justice perspective in introducing these programmes has been a failure to consider the educational inequalities inherent in the English educational system that make any attempt to be more selective almost certain to lead to a reduction in students from diverse backgrounds (Dillon, 2007; Nahai, 2013; Kelly \& Northrop, 2015). Concerns related to the lack of diversity on fast-track programmes were raised in early evaluations, and have continued to be a concerning feature as these programmes have expanded (Smith et al., 2013; Maxwell et al., 2016; Maxwell et al., 2018). For example, postgraduate social work education overall has 38\% Black, Asian and Minority Ethnic (BAME) students (Skills for Care, 2018), compared to recent cohorts of Think Ahead and Frontline who had 16\% and 18\% respectively (Think Ahead, 2017; Frontline, 2018b). Most concerning, the fast-track numbers are also substantially lower than the general higher education population in England, where $27 \%$ of students are from BAME groups (Skills for Care, 2018).

Disparities are also seen in relation to social class, which Belmi, Neale, Reiff. and Ulfe (2019) define as 'a multidimensional construct that encompasses people's objective resources (i.e. income, education, parental education) as well as their subjective assessments of their standing in society' (p.2). In line with this definition, there is clear evidence that students on social work fast-track programmes experience social advantage when compared to students on other qualifying routes. Maxwell et al. (2016) found that $59 \%$ of the first Frontline cohort had a parent with a degree, compared to $31 \%$ of the wider student cohort. These class disparities have been consistently maintained, and in a later evaluation of Frontline it was found that participants were more likely to have gone to private school and to have a parent who is a university graduate (Maxwell et al., 2018). Furthermore, there are concerns related to the condensed nature of these fast-track programmes, and the implications for diversity that this creates. Smith et al. (2013) and Baginsky and Teague (2013) recognised in early 
evaluations of Step Up that the demanding nature of the shorter programme meant it was important to have few external responsibilities. This has been borne out in fast-track programmes as they continued, with Maxwell et al. (2018) finding that only $4 \%$ of Frontline participants had caring responsibilities, and all of those were as a secondary carer. These factors have a disproportionate impact on student populations who are more likely to have caring responsibilities, including working class students (Stevenson \& Clegg, 2011), women (O'Shea, 2014) and mature students (Baglow \& Gair, 2019). Unsurprisingly then, Frontline and Think Ahead students are also substantially more likely to be male than social workers on other qualifying routes (Think Ahead, 2017; Frontline, 2018b).

The inequality that is apparent in social work fast-track programmes is consistent with the inequalities that are apparent at all levels of the English education system, which Reay (2017) described as operating 'as an enormous academic sieve, sorting out the educational winners from the losers in a crude and often brutal process that prioritises and rewards upper and middle class' (p.26). Going to an independent school or college makes an individual substantially more likely to attend higher education, and in particular to attend the most selective universities (Department for Education, 2018). Independent school fees in England average about $£ 17,000$ per years, a figure out of reach for the vast majority of families (Montacute, 2018). Predictably, therefore, research consistently shows that students from disadvantaged backgrounds are substantially less likely to apply, attend or achieve success in higher education and in particular in the most selective universities (Boliver, 2013; Mirza, 2018; Mallman, 2017; Montacute, 2018; Connell-Smith \& Hubble, 2018).

These educational inequalities go some ways towards explaining why social work fast-track programmes recruit more white, middle class, young and male students than other routes into social work. However, there are a number of other factors related to these programmes that mean they appeal to these demographics, including how they are marketed and the substantial financial incentives they provide. Ingram and Allen (2018) have explored the way that marketing material aimed at recent graduates can be used to send implicit messages to 
potential recruits about who is expected to apply. An example of this is when Think Ahead utilised the actor and presenter Stephen Fry in their marketing for the organisation (Think Ahead, 2015). Stephen Fry has been described as the epitome of the contemporary gentleman scholar', based on his accent, his interests and his Cambridge education (Mills, 2011: 142). Think Ahead (2017) also utilises student testimonials in their marketing that indicate they could have worked in finance instead of social work. Duggan (2017) examines how this type of discourse is common in the promotion of fast-track programmes in both teaching and social work, and implicitly suggesting that these individuals should be commended for forgoing higher salaries, or what he terms micro-philanthropy. The marketing campaigns for these programmes also focus substantially on the concept of leadership (Frontline, 2018a; Think Ahead, 2017). Marketing research shows that the use of terms that are traditionally associated with masculinity, including leadership, can discourage women from applying to graduate roles and positions (Gaucher, Friesen \& Kay, 2011). These issues are all exacerbated by the wide reach of the marketing for these programmes, including being promoted by successive governments as the preferred entry route to the profession (Jones, 2019).

The decreased diversity on these fast-track programmes is perhaps most concerning due to the substantial financial advantages that students on these programmes experience. There are no tuition fees charged for Think Ahead and Frontline students (Moriarty \& Manthorpe, 2018). Frontline and Think Ahead students also receive a bursary of approximately $£ 17,000-$ 19,000 for their first year and a salary of up to $£ 35,000$ in their second year, compared to other post graduate social work students who receive an approximate bursary of $£ 3,500$, which does not even cover their tuition fees (Skills for Care, 2018; Moriarty \& Manthorpe, 2018). Step Up students similarly receive a bursary of almost $£ 20,000$ during their course (Moriarty \& Manthorpe, 2018). Unsurprisingly, the real cost to the government is also much higher for fasttrack programmes. Cutmore and Roger (2016) found that each Frontline student costs $£ 45,323$, while Step Up students cost $£ 40,413$, compared to $£ 23,225$ for traditional social work 
masters programmes. Frontline and Think Ahead also receive significant financial support from by private interests and philanthropy, meaning that the actual money that goes into these organisations is even greater (Murphy, 2016; Jones, 2019).

At the same time as these substantial investments are being made into elitist programmes, social workers on traditional university programmes in England have seen their financial position deteriorate rapidly, including the introduction of a cap on the number of bursaries and the removal of first year undergraduate bursaries (Department of Health, 2013). These changes come alongside wider developments in higher education that have impacted on the value of the bursary in real terms, including a rise in student loan interest rates and an increase in tuition fees (Moriarty \& Manthorpe, 2018). Considering fast-track students are more likely to come from financially advantaged backgrounds, it needs to be accepted that what is being created in England is a social work education system whereby those most in need of financial support are least able to access it, and those who are least able to pay it back are going to finish their education with the most debt.

\section{Leadership Cadre}

The diversity issues that have been presented here thus far becomes more significant when it is recognised that fast-track social work programmes do not merely seek to supplement the social work profession with their graduates, but intend that these elite graduates will in fact become leaders within the profession (MacAlister et al., 2012; Clifton \&Thorley, 2014). For example, a central part of the Frontline programme is a leadership development programme delivered by a private outside consultancy (Murphy, 2016). Unsurprisingly then, the Dartington Social Research Unit (DSRU, 2017), in an evaluation of Frontline, found of Frontline graduates that 'given their qualifications, they are likely to be quickly promoted to leadership or management positions' (p.22). The advantages these graduates experience post-qualifying are also likely to be maintained by virtue of their membership of the elite cadre of graduates that these programmes hope to create (MacAlister et al., 2012; Clifton \& Thorley, 2014). This can be seen manifest in the formation of the Frontline Fellowship, an organisation into which 
Frontline graduates are automatically enrolled following graduation, and which provides 'the resources and support to lead positive change' (Frontline, 2018a: p.9). Membership to these types of exclusive social networks and groups has been shown to be an important tool utilised by elite groups and organisations to maintain their position of advantage in society (Bathmaker, Ingram \& Waller, 2013).

Unfortunately, social work as a profession already has a recognised issue with diversity in leadership, and the focus of these programmes on leadership is likely to exacerbate this. A particular concern that is frequently raised in relation to social work leadership is that despite women being the numerical majority within the profession, men tend to disproportionately dominate positions that are high-status and well-paid (Haworth, Miller \& Schaub, 2018). Williams (1992) described this as the glass escalator effect, whereby societal misconceptions that men are better suited to leadership positions leads them to quickly find promotion within numerically female dominated professions. This concept of the glass escalator has been updated and reviewed since it was originally introduced, and it is increasingly recognised that it is straight, white men from middle class backgrounds who are uniquely able to take advantage of the glass escalator effect (Wingfield, 2009; Williams, 2013). Parker and Crabtree (2014) found evidence of this in social work education in England, showing how male social workers were more likely to feel an expectation to take on leadership roles, even as students. These issues are likely to be compounded by the class advantage that many students in fasttrack programmes experience, which means they are more likely to display overconfidence in their abilities, a trait that has been positively correlated with fast career progression (Belmi et al., 2019). While there have been calls to support more men to enter social work (Schaub, 2015), there is a serious concern with those men coming mostly through disproportionately well-funded, higher status and leadership focused routes.

\section{Impact}

In a highly influential report into social work education in England, Croisdale-Appleby (2014) explored the potential impact of fast-track programmes, suggesting that 'provided the courses 
themselves are rigorously assessed as being fit for purpose, the inclusion of additional numbers of proven high calibre entrants to the qualification process can only be of potential value' (p.27). Indeed, if the value of these new entrants into the profession could be clearly demonstrated it may even justify the disproportionately low diversity rates, large financial incentives and the rapid promotions graduates are expected to be rewarded with. However, a critical examination shows that far from being an asset, the approach taken by these programmes has the potential to substantially damage the social work profession in England through shifting valuable resources towards the recruitment and training of individuals who are less likely to remain committed to the profession and may not necessarily make the best social workers.

An important starting point for understanding the impact of social work fast-track programmes is to review their antecedents in the teaching profession. Fast-track social work programmes have consistently been stated to be based on the perceived successes of similar programmes in teaching, in particular Teach First, a fast-track route into the teaching profession in England and Wales (MacAlister et al., 2012; Narey, 2014; DSRU, 2017). However, the evidence for the successes of fast-track teaching programmes is far from settled in the way that is often portrayed. Of particular concern is that various studies have put Teach First graduate two year professional dropout rates as between 30\%-70\% (Duggan, 2017). Unsurprisingly then, despite being around since 2002, Teach First has not prevented endemic teacher shortages from continuing in England, and policy approaches are increasingly shifting towards supporting teachers already in the profession (Department for Education, 2019).

While it is too early to determine the long term retention rates for fast-track social work graduates, there are many reasons to believe that they will be less likely to remain in the profession compared to other social work graduates. For example, Maxwell et al. (2018) found that Frontline students were more likely to have decided to join the social work profession in the last year, indicating that they could have less commitment to the profession. This statistic also increases the potential that some students could be strategically exploiting the well- 
funded nature of these programmes to pad out their experience, or as a stepping stone to a job role outside of social work. Bathmaker et al. (2013) discuss how higher education students from middle and upper class backgrounds are particularly adept at 'playing the game' to enhance their job prospects in this way (p.724). Teach for America, a fast-track teaching programme which influenced Teach First, has been criticised for the way that it has been utilised by young people as a way of gaining impressive experience without substantial financial cost (Ravitch, 2010; Deresiewicz, 2014). Duggan (2017), therefore, raises a legitimate concern that graduates of these fast-track programmes in England are set up as leaders for life, but not necessarily as social workers or teachers for life.

Even if these students initially intend on staying in the profession long term, once they enter the profession and experience the realities of frontline practice, they may be quicker to leave than other graduates. The point has been made several times that if these students were attracted to study social work due to the large financial incentives, then they may also be more inclined to be attracted away from the profession by financial incentives elsewhere (CroisdaleAppleby, 2014; Duggan, 2017). Graduates from the most selective universities have significantly more earning potential than those who do not attend these institutions, and so these students could look to utilise this potential if they are not satisfied with the profession they are in (Boliver, 2013; Montacute, 2018). Considering the rapidly expanding research that shows that social work working conditions are some of the worst in England (Holmes, Miscampbell, \& Robin, 2016; Ravalier \& Boichat, 2018), these concerns appear to be particularly prescient. While the goal of social work obviously should not be to trap individuals in a profession where they are treated poorly because they have no other options, it has to be recognised that until the endemic poor treatment of social workers in England is remedied, these fast-track graduates are going to be more likely to leave the profession due to the availability of alternative options.

The primary focus on academic credentials in the selection process for these programmes could also devalue the importance of lived experiences that has traditionally been seen as 
central to the recruitment of social work students. Jones (2006) found that key social work values of inequality, discrimination and emancipation were most meaningful to those individuals who can relate them to their own experiences. Of particular significance to this article, in a study of social work students graduating in Scotland, where fast-track programmes have not taken hold, only $6 \%$ of participants rated academic background as the most important factor that should be accounted for in the student selection process, with $78 \%$ agreeing that it should be personal qualities and values (Cree, Morrison, Clapton, Levy \& Ingram, 2018).

There are also pertinent concerns that students who are considered bright or talented in the traditional academic sense may not necessarily make the best social workers. Bogo et al. (2006), in a Canadian study, found that social work students who were considered bright could find it difficult to remain present for clients, instead shifting the focus to what would come next. Similarly, Dillon (2007) found that social work admissions tutors in England had specific concerns about high achievers who could believe that they have little to learn and already know it all, leading to a lack of sensitivity and empathy when it came to working with service users. These points lead on to an often neglected and highly ironic point in relation to the still commonly used term 'best and brightest' for describing the most desirable social work students (for example, Department for Education, 2016: p.5). The term 'best and brightest' was introduced into the common lexicon through the title of the book 'The Best and the Brightest' by Halberstam (1972) as a disparaging term to conceptualise the young, high achieving but ultimately naïve individuals who helped orchestrate the United States' involvement in the Vietnam war. In discussing this point, Deresiewicz (2014) looks at how this concept of 'best and brightest' is now often uncritically utilised in educational contexts, reminding us it actually refers to 'the so called whiz kids whose arrogance and overconfidence enmeshed [America] in a quagmire' (p.225).

Evidence has started to accumulate that shows that some students qualifying through these fast-track programmes indeed may not be best suited or sufficiently prepared for the realities of frontline social work. Smith et al. (2018), for example, found that some Step Up graduates 
experienced 'a huge gap' between their training and the realities of practice (p.41). In their evaluation of Frontline, the DSRU (2017) found a consensus amongst Frontline students that they experienced a shock when moving from the supportive context of Frontline practice units to the realities of social work practice. Some of these issues with practice preparedness may not relate to student selection, but instead the controversially narrow curriculum that the fasttrack nature of these programmes necessitates (Higgins, 2015; Murphy, 2016; Thoburn, 2017; Duggan, 2017; Cartney, 2018; Herrero \& Charnley, 2019). Either way, these competency concerns are significant enough that serious questions have been asked as to whether graduates through fast-track programmes will be sufficiently qualified to practice social work outside of England (Murphy, 2016; Cartney, 2018). Therefore, for the sake of all students studying to become social workers, this model of education should be reconsidered.

\section{Social Justice}

The way that the success story of WP in social work education has been torn down in is a testament to just how pervasive inequality in English higher education is, and questions the reality of the national commitment to the WP agenda. The remit of this policy agenda is increasingly limited to widening access to only the most selective universities and the brightest students, with the Department for Education (2017) going so far as to commission behavioural insight trials into how to encourage applications to the most selective universities. Blackman (2017) has raised concerns that 'we seem to be moving to a situation where the Department for Education is a marketing department for the most selective universities' (p.34). It stands to reason then that the success story of WP in social work education, which fails to fit neatly into this paradigm, would be marginalised rather than celebrated. Unfortunately, while the Department of Education (2017) has claimed that 'huge strides' have been made in relation to WP into these selective universities (p.23), several studies have shown how selective universities and those who represent them, either through oversimplification or duplicitousness, present data in a way that obscures the reality of continued inequality (Boliver, 2015; Kelly, 2019). Nahai (2013) examined the experiences of Oxford admissions 
tutors and came to the conclusion that due to the deep rooted and rising inequality in British society any attempt to widen access while also keeping previous academic achievement as the primary entry criteria is destined to failure.

In order to challenge this approach to WP, social work education should once again take the lead, shifting the focus from separating students to bringing them together, including in relation to prior academic achievement. This would be more in line with a social justice model of education, prioritising diversity and equality over academic excellence and social segregation (Reay, 2017). In presenting his vision for a comprehensive university system, Blackman (2017) outlines the pedagogical advantages of jointly educating students from varied academic backgrounds in this way. He gives the example of students who find a topic easier supporting those who find it more difficult, generating significant benefits to both parties in the process. Research shows that one of the core areas that students in higher education benefit from when learning in mixed-ability settings is in leadership capacity, stemming from the improved aptitude students gain for understanding the world through alternative perspectives (Jayakumar, 2008). As Duffy (2010) aptly recognises: 'diversity brings change, beauty and interest to human life, creating opportunities for meaningful exchange in a way that sameness never can' (p.259).

Introducing a model like this is likely to meet resistance, as many see it as part of the natural order for students to be separated based on their previous academic achievements (Francis, et al., 2017). However, the increasing flow of literature and evidence showing the negative impact that fast-track programmes are having on social work in England means that social workers and social work educators are going to be increasingly unlikely to tolerate the current system and inherent inequalities (Higgins, 2015; Murphy, 2016; Thoburn, 2017; Duggan, 2017; Herrero \& Charnley, 2019). There is already evidence that fast-track students can receive a hostile reception from social work teams due to the route that they have qualified through (Maxwell et al., 2016; DSRU, 2017). While this type of individual intimidation should obviously not be encouraged, it may be unavoidable considering social workers in England 
have a professional requirement to address oppression and promote diversity (British Association of Social Work, 2018). Either way, these responses do show that social workers recognise the inequity of the programmes that these individuals have graduated through, and will not tolerate the elitism and inequality that they perpetuate in silence. Attempts should therefore be made to channel these frustrations away from individual graduates and towards the systems and structures that perpetuate the inequalities on which these programmes are based.

\section{Conclusion}

This article has shown that fast-track programmes in England, through shifting the focus of selection towards prior academic achievement and attendance at selective universities, are designed in a way that maintains, rather than challenges, the educational inequalities that are intrinsic to the English education system at all levels. For now these fast-track programmes seem to be a uniquely English affliction, and the European Association of Schools of Social Work has stated that the structure of fast-track social work education is incompatible with European standards under the Bologna agreement (Cartney, 2018). However, it is important to recognise how quickly these programmes were introduced and have expanded in England, and there are a number of contemporary developments that mean that this experience could be replicated elsewhere without adequate resistance. Fast-track social work education models stem from a neoliberal ideological perspective (Jones, 2019), and the increasing influence of neoliberalism in social work and social work education across Europe could gradually create a climate that is more amenable to these models (Albuquerque, 2019; Herrero \& Charnley, 2019; Jonsson, 2019). The fact that both Think Ahead and Frontline were introduced following reports by the Institute for Public Policy Research, a self-described think tank, should also be considered significant within the contemporary European policy context, where think tanks are seeing an upsurge in influence (Bajenova, 2019). This point becomes all the more prescient when it is acknowledged that social work education internationally has often taken its lead from developments that have originated in the UK (Vicary, Cree and Manthorpe, 2018). Social 
work educators should take the lead in promoting alternative models, and keep the focus on widening participation, social justice and bringing students together. If social work educators are going to instil a belief in social justice and the value of diversity in students, then they need to practice what they preach, and educate students in a way that exemplifies these values rather than marginalising them or characterising them as a burden.

\section{Reference List}

Albuquerque, C. (2019). Social work's 'black hole' or 'phoenix moment'? Impacts of the neoliberal path in social work profession in Portugal. European Journal of Social Work, 22(2), 314-325.

Baginsky, M. \& Teague, C. (2013). Speaking from experience: The views of the first cohort of trainees of Step Up to Social Work. London: Department for Education.

Baglow, L. \& Gair, S. (2019). Mature-aged Social Work Students: Challenges, Study Realities, and Experiences of Poverty. Australian Social Work, 72(1), 91-104.

Bajenova, T. (2019). Rescaling expertise in EU policy-making: European think tanks and their reliance on symbolic, political and network capital. Globalisation, Societies and Education, 17(1), 61-77.

Bathmaker, A., Ingram, N. \& Waller, R. (2013). Higher education, social class and the mobilisation of capitals: recognising and playing the game. British Journal of Sociology of Education, 34(5-6), 723-743.

Belmi, P., Neale, M., Reiff, D. and Ulfe, R. (2019). The social advantage of miscalibrated individuals: The relationship between social class and overconfidence and its implications for class-based inequality. Journal of Personality and Social Psychology, Advance online publication: 10.1037/pspi0000187.

Blackman, T. (2017). The Comprehensive University: An Alternative to Social Stratification by Academic Selection. Oxford: Higher Education Policy Institution.

Bogo, M., Regehr, C., Woodford, M., Hughes, J., Power, R. \& Regehr, G. (2006). Beyond competencies: Field instructors' descriptions of student performance. Journal of Social Work Education, 42(3), 579-594.

Boliver, V. (2013). How fair is access to more prestigious UK universities?. British Journal of Sociology, 64(2), 344-364.

Boliver, V. (2015). Lies, damned lies, and statistics on widening access to Russell Group universities. Radical Statistics, 113, 29-38.

British Association of Social Work (2018). Professional Capabilities Framework for Social Work in England: The 2018 Refreshed PCF. London: BASW.

Brooks, R. (2017). The construction of higher education students in English policy documents. British Journal of Sociology of Education, 39(6), 745-761.

Cartney, P. (2018) 'Developing Rich Pedagogies for Fast-Track Social Work Education', British Journal of Social Work, 48, 1315-1332. 
Children's Workforce Development Council (2010). Invitation to tender and specification: Evaluation of CWDC's Step Up to Social Work programme. Leeds: Children's Workforce Development Council.

Cleary, T. (2018). Social Work Education and the Marketization of UK Universities. British Journal of Social Work, 48(8), 2253-2271.

Clifton, J. \& Thorley, C. (2014). Think Ahead: Meeting the Workforce Challenges in Mental Health Social Work. London: Institute for Public Policy Research.

Connell-Smith, A. \& Hubble, S. (2018). Widening participation strategy in higher education in England Briefing Paper 8204. London: House of Commons.

Cree, V., Morrison, R., Clapton, G., Levy, S. \& Ingram, R. (2018). Selecting social work students: lessons from research from Scotland. Social Work Education, 37(4), 490-506.

Croisdale-Appleby, D. (2014). Re-visioning social work education: An independent review. London: Department of Health.

Cutmore, M. \& Roger, J. (2016). Comparing the costs of social work qualification routes. London: Department for Education.

Dartington Social Research Unit (2017). Frontline Social Work Training: an evaluation. Dartington: DSRU.

Department for Education (2016). Children's social care reform: A vision for change. London: Department for Education.

Department for Education (2017). Unlocking Talent, Fulfilling Potential: A plan for improving social mobility through education. London: Department for Education.

Department for Education (2018). Widening Participation in Higher Education, England, 2016/17 age cohort: Official Statistics. London: Department for Education.

Department for Education (2019). Teacher Recruitment and Retention Strategy. London Department for Education.

Department of Health (2013). Reforming the Social Work Bursary: The Government response to the consultation. London: Department of Health.

Deresiewicz, W. (2014). Excellent Sheep: The Miseducation of the American Elite and the Way to a Meaningful Life. New York: Free Press.

Dillon, J. (2007). The conundrum of balancing widening participation with the selection of satiable students for social work education. Social Work Education, 26(8), 827-841.

Duffy, S. (2010). The Citizenship Theory of social justice: exploring the meaning of personalisation for social workers. Journal of Social Work Practice, 24(3), 253-267.

Duggan, J. (2017). Fast-track leadership development programmes: the new microphilanthropy of future elites. In H. Gunter, D. Hall \& W. Apple (Eds.) Corporate Elites and the Reform of Public Education (pp.135-146), Bristol: Policy Press.

Fairtclough, A., Bernard, C., Fletcher, J. \& Ahmet, A. (2014). Black social work students' experiences of practice learning: Understanding differential progression rates. Journal of Social Work, 14(6), 605-624.

Fletcher, J., Bernard, C., Fairtclough, A. \& Ahmet, A. (2015). Beyond Equal Access to Equal Outcomes: The Role of the Institutional Culture in Promoting Full Participation, Positive InterGroup Interaction and Timely Progression for Minority Social Work Students. British Journal of Social Work, 45(1), 120-137. 
Francis, B., Archer, L., Hodgen, J., Pepper, D., Taylor, B. and Travers, M. (2017). Exploring the relative lack of impact of research on ability grouping in England: a discourse analytic account. Cambridge Journal of Education, 47, 1-17.

Frontline (2018a). Dare to Change: Leadership Development Programme Children's Social Work. London: Frontline.

Frontline (2018b). Impact Report 2018. London: Frontline.

Garrett, P. (2016). Introducing Michael Gove to Loic Wacquant: Why Social Work Needs Critical Sociology. British Journal of Social Work, 46(4), 873-889.

Gaucher, D., Friesen, J. \& Kay, A. (2011). Evidence that gendered wording in job advertisements exists and sustains gender inequality. Journal of Personality and Social Psychology, 101(1), 109-128.

General Social Care Council (2007). Social Work Education in England: listening, learning, shaping: The 2006 Social Work Education Quality Assurance Report. London: GSCC.

General Social Care Council (2009). Raising standards: Social work education in England 2007-08. London: GSCC.

General Social Care Council (2010). Raising standards: Social work education in England 2008-09. London: GSCC.

General Social Care Council (2012). Regulating Social Work Education (2001-12). London: GSCC.

Halberstam, D. (1972). The Best and the Brightest. New York: Penguin Random House.

Haworth, S., Miller, R. \& Schaub, J. (2018). Leadership in Social Work (and can it learn from clinical healthcare). Birmingham: University of Birmingham.

Herrero, M. \& Charnley, H. (2019). Human rights and social justice in social work education: A critical realist comparative study of England and Spain. European Journal of Social Work, 22(2), 225-237.

Higgins, M. (2015). The Struggle for the Soul of Social Work in England. Social Work Education, 34(1), 4-16.

Holmes, E., Miscampbell, G. \& Robin, B. (2016). Reforming Social Work: Improving social worker recruitment, training and retention. London: Policy Exchange.

Holmstrom, C. (2014). Suitability for Professional Practice: Assessing and Developing Moral Character in Social Work Education. Social Work Education, 33(4), 451-468.

Ingram, N. \& Allen, K. (2018). Talent-spotting' or 'social magic'? Inequality, cultural sorting and constructions of the ideal graduate in elite professions. The Sociological Review, 67(3) 723740 .

Jayakumar, U. (2008). Can higher education meet the needs of an increasingly diverse and global society? Campus diversity and cross-cultural workforce competencies. Harvard Educational Review, 78(4), 615-651.

Jones, K. (2006). Valuing Diversity and Widening Participation: The Experiences of Access to Social Work Students in Further and Higher Education. Social Work Education, 25(5), 485500.

Jones, R. (2019). In Whose Interest? The Privatisation of Child Protection and Social Work. Bristol: Policy Press. 
Jonsson, J. (2019). Servant of a 'sinking titanic' or actors of change? Contested identities of social workers in Sweden. European Journal of Social Work, 22(2), 212-224.

Kelly, A. (2019). A new composite measure of ethnic diversity: Investigating the controversy over minority ethnic recruitment at Oxford and Cambridge. British Educational Research Journal, 45(1), 41-82.

Kelly, S. \& Northrop, L. (2015). Early Career Outcomes for the "Best and the Brightest": Selectivity, Satisfaction, and Attrition in the Beginning Teacher Longitudinal Survey. American Educational Research Journal, 52(4), 624-656.

Lall, M. \& Morley, L. (2004). Social Disadvantage and Widening Participation in Higher Education. London: Neighbourhood Renewal Office.

Langlands, A. (2005). The Gateways to the Professions Report. Nottingham: Department for Education and Skills.

Liu, B. (2017). Intersectional impact of multiple identities on social work education in the UK. Journal of Social Work Education, 17(2), 226-242.

MacAlister, J., Crehan, L., \& Olsen, A. (2012). Front Line: Improving the Children's Social Work Profession. London: Institute for Public Policy Research.

Mallman, M. (2017). The perceived inherent vice of working-class university students. The Sociological Review, 62(2), 235-250.

Maxwell, N., Scourfield, J., de Villiers, T., Pithouse, A. \& Le Zhang, M. (2018). The pre-training characteristics of Frontline participants and mainstream social work students. British Journal of Social Work, 48(2), 487-504.

Maxwell, N., Scourfield, J., Le Zhang, M., de Villiers, T., Hadfield, M., Kinnersley, P., Metcalf, L., Pithouse, A. \& Tayyaba, S. (2016). Independent evaluation of the Frontline Pilot: Research report. London: Department of Education.

Mills, B. (2011). The Guardians of the General Interest: Discourses of Knowledge in Ql', Television and New Media. 12(2), 136-153.

Mirza, H. (2018). Racism in Higher Education: 'What Then, Can Be Done?. In J. Arday \& H. Mirza (Eds.) Dismantling Race in Higher Education (pp. 3-26). Basingstoke: Palgrave Macmillan.

Montacute, R. (2018). Access to Advantage: The influence of schools and place on admissions to top universities. London: The Sutton Trust.

Moriarty, J. \& Manthorpe, J. (2018). Literature review on the social work bursary and student finance. London: Social Care Workforce Research Unit.

Murphy, T. (2016). The Frontline Programme: Conservative ideology and the creation of a social work officer class. Critical and Radical Social Work. 4(2), 279-287.

Nahai, R. (2013). Is meritocracy fair? A qualitative case study of admissions at the University of Oxford. Oxford Review of Education, 39, 681-701.

Narey, M. (2014). Making the education of social workers consistently effective. London: Department for Education.

National Committee of Inquiry into Higher Education (1997). Higher Education in the Learning Society (Dearing Report). London, HMSO. 
O'Shea, S. (2014). Transitions and turning points: exploring how first-in family female students story their transition to university and student identity formation. International Journal of Qualitative Studies in Education, 27(2), 135-158.

Parker, J. \& Crabtree, S. (2014). Fish Need Bicycles: An exploration of the perceptions of male social work students on a qualifying course. British Journal of Social Work, 44(2), 310-327.

Ravalier, J. and Boichat, C. (2018) UK Social Workers: Working Conditions and Wellbeing, Bath: Bath Spa University.

Ravitch, D. (2010). The Death and Life of the Great American School System: How testing and choice are undermining education. New York: Basic Books.

Reay, D. (2017). Miseducation: Inequality, education and the working class. Bristol: Policy Press.

Schaub, J. (2015). Issues for Men's Progression on English Social Work Honours and Postgraduate Degree Courses. Social Work Education, 34(3), 315-327.

Skills for Care (2018). Social Work Education: Skills for Care analysis of Higher Education Statistics Agency Data. London: Skills for Care.

Smith, R., McLenachan, J., Venn, L.., Weich, H. and Anthony, D. (2013). Step up to Social Work Programme Evaluation 2012: The Regional Partnerships and Employers Perspective. London: Department for Education.

Smith, R., Stephanova, E., Venn, L., Carpenter, J. \& Patsios, D. (2018). Evaluation of Step Up to Social Work, Cohorts 1 and 2: 3-years and 5-years on: Research report. London: Department for Education.

Social Work Task Force (2009). Building a Safe Confident Future: The Final Report of the Social Work Task Force. London: SWTF.

Stevenson, J. \& Clegg, S. (2011). Possible selves: students orientating themselves towards the future through extracurricular activity. British Educational Research Journal, 37(2), 231246.

Think Ahead (2015, October 10). World Mental Health Day: Stephen Fry encourages graduates to apply to Think Ahead. Retrieved from https://thinkahead.org/news-item/worldmental-health-day-stephen-fry-encourages-graduates-to-apply-to-think-ahead/

Think Ahead (2017). Our Impact. London: Think Ahead.

Thoburn, J. (2017). In defence of a university social work education. Journal of Children's Services, 12(2-3), 97-106.

Vicary, S., Cree, V. and Manthorpe, J. (2018). Social work education - A local and global history. Practice, 4, 223-226.

Williams, C. (1992). The Glass Escalator: Hidden Advantages of Men in the Female Professions. Social Problems, 39(3), 253-267.

Williams, C. (2013). The Glass Escalator, Revisited: Gender Inequality in Neoliberal Times, SWS Feminist Lecturer. Gender and Society, 27(5), 609-629.

Wingfield, A. (2009). Racializing the glass escalator: Reconsidering men's experiences with women's work. Gender and Society, 23(1), 5-26. 
